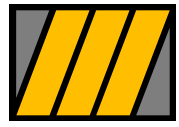

ESCUELA DE NEGOCIOS Universidad Torcuato Di Tella

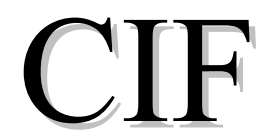

Centro de Investigación en Finanzas

Documento de Trabajo 02/2005

\title{
A (New) Country Insurance Facility
}

\author{
Tito Cordella \\ IMF \\ and
}

Eduardo Levy Yeyati

Universidad Torcuato Di Tella
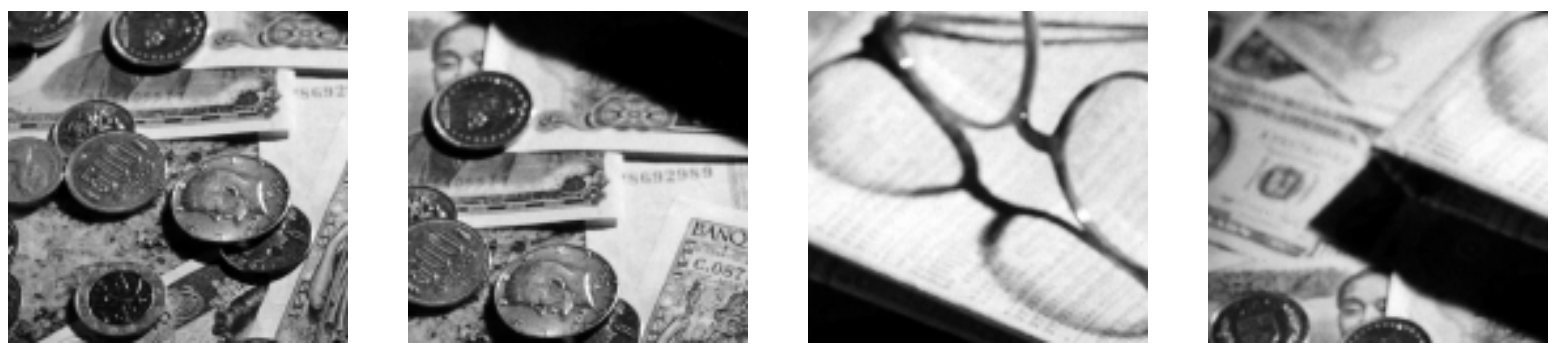

Almirante Sáenz Valiente 1010, C1428BIJ Buenos Aires • Tel: (54 11) 4783.3112

Fax: (54 11) 4783.3220 - Web site: www.utdt.edu/departamentos/empresarial/cif/cif.htm 


\title{
IMF Working Paper
}

\author{
Research Department
}

\section{A (New) Country Insurance Facility}

Prepared by Tito Cordella and Eduardo Levy Yeyati ${ }^{1}$

Authorized for distribution by Arvind Subramanian

January 2005

\begin{abstract}

\section{This Working Paper should not be reported as representing the views of the IMF.} The views expressed in this Working Paper are those of the author(s) and do not necessarily represent those of the IMF or IMF policy. Working Papers describe research in progress by the author(s) and are published to elicit comments and to further debate.
\end{abstract}

To cope with the self-fulfilling liquidity runs that triggered many recent financial crises, we propose the creation of a country insurance facility. The facility, which we envisage as complementary to the existing multilateral lending facilities, would provide eligible countries with automatic access to a credit line at a predetermined interest rate. Eligibility criteria should be easily verifiable, focus on debt sustainability, and take into account the currency and maturity composition of the debt. Other critical design issues considered here include the size of the facility, its duration and charges, and the exit costs for a country that loses eligibility.

JEL Classification Numbers:F30, G22, H60

Keywords: Country insurance, liquidity crises, international financial architecture

Author’s E-Mail Address:tcordella@imf.org; ely@utdt.edu

\footnotetext{
${ }^{1}$ IMF Research Department and Universidad Torcuato di Tella, respectively. We are indebted to Eduardo Borensztein, Giovanni Dell'Ariccia, Enrica Detragiache, Haizou Huang, Jaewoo Lee, Eduardo Ley, Olivier Jeanne, Jun Il Kim, Paolo Mauro, Alessandro Prati, Raghuram Rajan, Arvind Subramanian, Angel Ubide, and Jeromin Zettelmeyer, as well as to participants in the IMF/RES Country Insurance Workshop for their constructive comments and suggestions. Naomi Griffin provided excellent research assistance.
} 


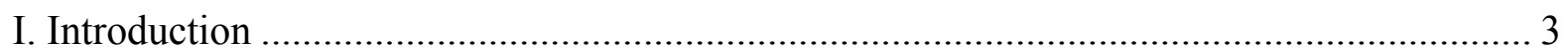

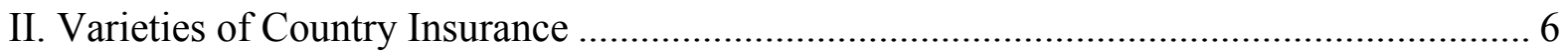

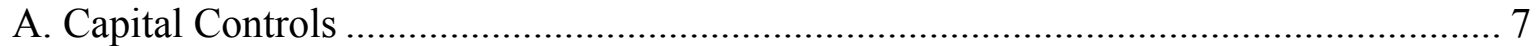

B. Self-Insurance

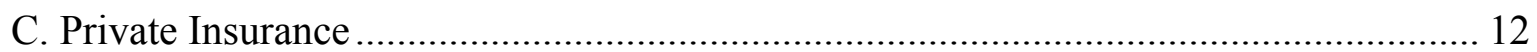

D. IMF-Led Packages ................................................................................................. 13

E. Regional Swap Agreements .................................................................................... 16

III. A New Country Insurance Facility .................................................................... 17

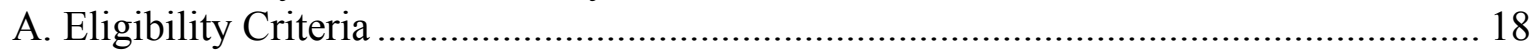

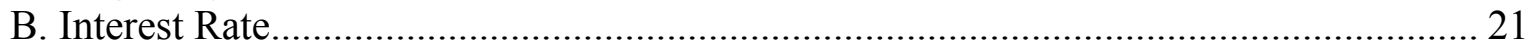

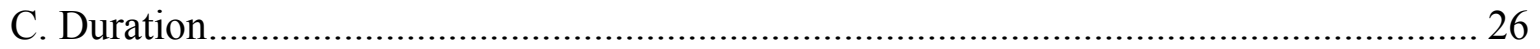

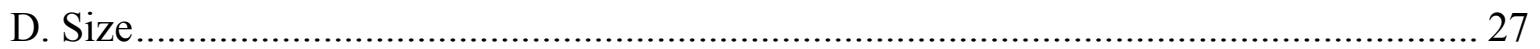

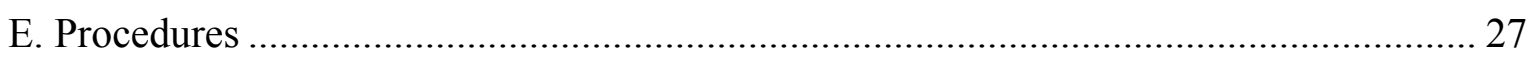

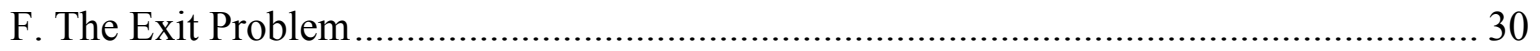

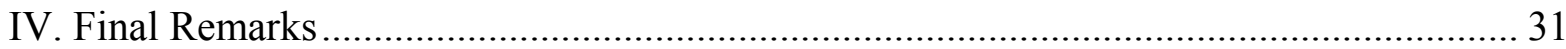

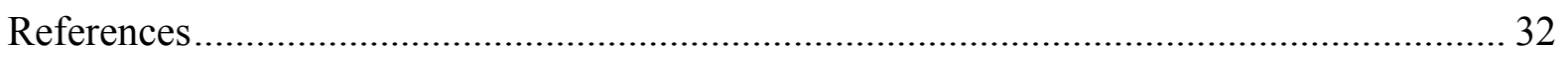

\section{Text Tables}

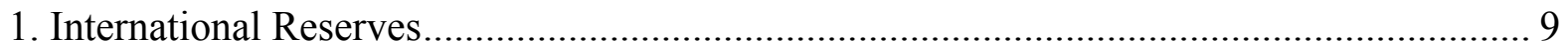

2. Twelve-month Real Exchange Rate Changes in Emerging Economies ........................... 19

3. Eligibility and Country Characteristics................................................................. 22

4. Eligibility Criteria and EMBI Country Spreads...................................................... 25

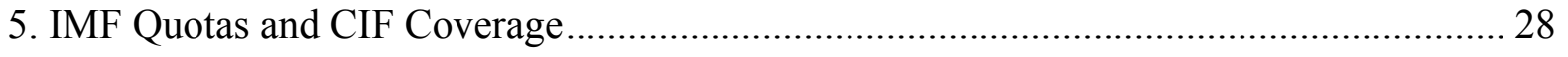

Figure 1. EMBI Spreads in the 12-month Preceding Request for an IMF Program.............. 14 


\section{INTRODUCTION}

There is an increasing consensus that self-fulfilling liquidity runs have triggered many of the recent financial crises, as sudden increases in perceived rollover risk set off an escalation of interest rates that rendered otherwise sustainable debt levels unsustainable. This second generation, multiple-equilibria account of balance of payments crises, reminiscent of Diamond and Dybvig's (1983) model of self-fulfilling bank runs, have been highlighted, among many others, by Calvo (1988) and, more recently, Cole and Kehoe (1996). ${ }^{2}$

Liquidity runs - rather than deeper-rooted fundamental problems-seem to underlie even some cases that ultimately ended up in debt restructurings. It could be argued, for instance, that Ukraine or Pakistan, which rescheduled their external obligations without a nominal haircut and managed to repay or stabilize debt service thereafter, effectively proved to be solvent at the rates committed in the exchange, well above high-grade interest rates at the time-albeit below the crisis rates demanded of them. ${ }^{3}$

In this context, a country insurance scheme could protect emerging markets from destabilizing confidence crises, in much the same way as deposit insurance or central bank lending of last resort helps avoid runs on domestic financial institutions. By insuring a country against self-fulfilling runs, such a scheme would avoid the persistent real costs associated with episodes of financial distress. In addition, it could extend the policymakers' planning horizon and foster their incentives to undertake reforms that strengthen a country's resilience toward external shocks and reduce the likelihood of solvency crises. ${ }^{4}$ However, an ill-designed scheme, by weakening the link between the cost of borrowing and the quality of macroeconomic fundamentals, is likely to lessen market discipline and detract from reform incentives. Thus, a country insurance scheme needs to strike the right balance between protecting a country from self-fulfilling liquidity runs, and avoiding complacency toward unsound policies that can ultimately lead to solvency crises.

In this article, we propose a new country insurance facility (CIF) to cope with short-lived self-fulfilling liquidity crises in emerging markets. ${ }^{5}$ The facility is reminiscent of the way in

\footnotetext{
${ }^{2}$ Hausmann and Velasco (2004) present an updated survey of the debate on the nature of financial crisis.

${ }^{3}$ For instance, according to Sturzenegger and Zettelmeyer (2004), although Pakistan was unable to pay the hefty 24 percent demanded by the market at the time of the debt exchange, it was able to pay (hence, was solvent at) a more reasonable 10 percent interest rate. In this case, the associated NPV haircut was merely the reflection of exceptionally high risk premia.

${ }^{4}$ For a discussion along these lines, see Cordella and Levy Yeyati (2004).

${ }^{5}$ Our proposal builds on previous background internal analyses of ex ante conditionality and rules-based variants of the contingent credit lines conducted by IMF staff, including the Strategic Issues Division in the Research Department.
} 
which central banks operate in their role of lenders of last resort. It entails the creation of a liquidity window, through which eligible countries can have automatic access to a line of credit at a predetermined interest rate to cover short-term financing needs. By offering instant liquidity at reasonable rates, the CIF would place a ceiling on the rollover costs faced by the country, avoiding liquidity runs triggered by unsustainable refinancing rates. ${ }^{6}$

For the scheme to work, however, there are a number of critical design and implementation issues that need careful consideration. It is imperative, for example, that countries do not exploit the CIF to build up an excessive stock of debt at a subsidized price, which would ultimately require net transfers (to the country) from the insurer (through a restructuring of the lines of credit) or the preexisting creditors whose junior claims would be diluted.

To that end, careful thought should be given to the definition and calibration of a set of readily verifiable conditions that make a particular country eligible for the CIF. These conditions should focus on debt sustainability issues (for example, the level and evolution of the debt-to-GDP ratio and the fiscal deficit) based on both expected outcomes and risk exposures. They should also take into account the currency and maturity composition of the debt. Other critical design issues that have to be considered include the size of the facility, its duration and charges, and the exit costs for a country that loses eligibility due to adverse external shocks. The conditions would not only preserve the solvency of the insurer but also introduce strong incentives for policymakers to bring public debt to manageable levels.

To evaluate this facility vis-à-vis the existing alternatives, and to address related operational issues, we order the discussion around the following two questions: (i) how does a CIF compare with available varieties of insurance (including self-insurance through the accumulation of liquid international assets, arrangements available from international financial markets, and existing facilities provided by international and regional financial institutions); and (ii) what are the main conditions that a CIF has to satisfy in order to reduce the likelihood of self-fulfilling runs, while preserving both the insurer's solvency and the government's incentives to implement sustainable policies.

The idea that international financial institutions (IFIs) should offer a streamlined lending facility is not new. Indeed, the need to speed up the IMF lending process in the event of an “exceptionally large" capital account reversal was brought up as early as 1972, ${ }^{7}$ and a document laying out the main options for an expeditious facility (IMF, 1994) was debated at the IMF Board in late 1994 (right before the Mexican crisis). This debate gained further momentum after the Asian crises, which were largely viewed as the result of liquidity

\footnotetext{
${ }^{6}$ We come back to the definition of reasonable rates below. For the moment, it suffices to note that, in order to limit the use of the facility to exceptional cases (and following a standard lender of last resort practice), rates should be at a premium with respect to precrisis values.

${ }^{7}$ See De Vries (1985), p. 16.
} 
shortages. Since then, the idea that the IMF or other IFIs should act as international lender of last resort has been discussed extensively. ${ }^{8}$

On the other hand, the concept of ex ante conditionality - recently put to work in the IMF's contingent credit line (CCL) - has been central to recent proposals for IMF reform, although some degree of constructive ambiguity has been typically advocated to balance celerity and incentives.

The Council on Foreign Relations Task Force (1999) suggests that the cost of IMF assistance be commensurate with countries' crisis prevention efforts. In particular, for the case of countries hurt by contagion, it supports the creation of a new contagion facility "free of policy conditions." However, the report argues against automaticity, and explicitly rules out the possibility of prequalification. Furthermore, while it points out that eligibility decisions would be made quickly, disbursements would nonetheless require "a supermajority of creditor countries contributing to it to agree that this was indeed a systemic crisis" (p.110). In turn, the Report of the International Financial Institution Advisory Commission (2000), better known as the "Meltzer Report," proposed that only prequalified countries have access to Fund assistance (except on the rare occasions when a crisis poses a threat to the global economy), so that IMF lending is limited to the provision of liquidity to solvent countries. In a related work, Cohen and Portes (2004) also make a case for a simplified IMF lending facility to target liquidity runs. However, they emphasize that "nothing should be automatic in this process" as "IMF support remains conditional on taking appropriate measures" (p. 17).

The advantages of ex ante conditionality as an instrument to make more selective the use of financial assistance while giving countries the right policy incentives are highlighted by Jeanne and Zettelmeyer (2001). As these authors state, "the need for constructive ambiguity, however does not per se invalidate the case in favor of ex ante conditionality" (p. 424). Rather, it underscores the need to reconcile the two in practice.

Building on this ongoing debate, the facility depicted here emphasizes the need for automaticity (rather than celerity), an aspect that is critical to preempt liquidity runs, and that distinguishes the CIF from standard IMF facilities, including IMF-led rescue packages. Indeed, we envisage the CIF as strictly complementary with the latter: automaticity could be regarded as a reward to a subset of countries with manageable debt levels that can be credibly denied to noneligible countries with access to a Fund program. While the previous discussion suggests that the Fund (alone or together with other IFIs) is a natural candidate to provide a facility such as the CIF, it should be noted that the principles and design issues outlined below could be readily applied to arrangements provided by regional financial institutions with access to the needed liquidity.

\footnotetext{
${ }^{8}$ See, e.g., Fischer (1999).
} 
The paper proceeds as follows. In Section II, we discuss the concept of country insurance as it applies to liquidity crises, and review the varieties of insurance mechanisms currently available to developing economies and their shortcomings. In Section III, we describe a new country insurance facility, and outline its main characteristics (eligibility criteria, charges, size and maturity, and other operation procedures). Section IV briefly analyzes the effect of the proposed facility on government's incentives, recaps the main policy messages and concludes.

\section{VARIETIES OF COUNTRY INSURANCE}

Strengthening the current international financial architecture entails, among other things, enhancing crisis prevention mechanisms, and creating more effective crisis resolution tools. While most of the current debate is centered on the latter, ${ }^{9}$ in this paper we focus on the former, particularly in relation to what are increasingly regarded as avoidable self-fulfilling liquidity crises. Specifically, we are concerned with the tools that can help countries insure themselves against negative swings in market perceptions.

Country insurance, as defined in the introduction, has important similarities with standard insurance contracts. Under an insurance contract, the insurer pays with certainty a predefined sum to the insured party should a well-defined event occur. ${ }^{10}$ As noted, rollover risk (that is, uncertainty about access to sources of finance) is the main factor driving liquidity runs. Thus, the availability of "insurance money" with certainty is the basis for any country insurance scheme aimed at preventing self-fulfilling runs.

There are, however, obvious differences between the scheme proposed here and a typical insurance contract against, for instance, a natural disaster. Indeed, the instrumentation of a standard insurance contract against liquidity runs would be problematic for a number of reasons. First, insurable crises (and associated losses) would be hard to define in an uncontroversial way. Second, the conditions needed to mitigate moral hazard would have to be, in this case, extremely restrictive - and the fair premium to be paid up front prohibitively expensive. Finally, enrollment through the payment of the premium would be subject to the same signaling problems identified for the case of CCL (discussed below).

\footnotetext{
${ }^{9}$ These include the so-called statutory and market-based approaches, as represented by the sovereign debt restructuring mechanism (SDRM) proposal and the emphasis on the introduction of collective action clauses (CAC) in global bond contracts, respectively. See Roubini and Setser (2004) for a review.

${ }^{10}$ In most private insurance contracts, a premium is charged to the insured to guarantee the financial viability of the insurer to cover the claims. There are, however, insurance contracts in which premiums are not specified ex ante, or are paid by the insurer (usually a government) out of a more general budget (e.g., disability insurance).
} 
To better understand the nature of the facility we propose, the analogy with the operation of a central bank is helpful. Liquidity assistance, as typified by standing central bank facilities, aims at minimizing ambiguity in the terms and conditions of access - in contrast with crisis-management tools that call for a higher degree of discretion to mitigate moral hazard and preserve the central bank's solvency. ${ }^{11}$ While no net transfer is involved (beyond that implied by the difference between the attendant market rate and that charged by the central bank), by placing a ceiling on the bank's short-term funding costs, the central bank protects the bank against sudden liquidity shortages that could eventually compromise its solvency, providing what essentially amounts to interest rate insurance.

In this light, existing IMF facilities, with their slow disbursement and their emphasis on conditionality, are better equipped to deal with crisis resolution than to prevent liquidity runs. It is not surprising, then, that emerging markets have searched for alternative ways of insuring themselves against sudden shifts in market sentiment.

In what follows, we look at these alternative insurance mechanisms, which we broadly classify into (i) capital controls (or other forms of financial repression); (ii) self-insurance (mainly through the accumulation of substantial stocks of international reserves); and (iii) private insurance (including through the arrangement of contingent lines of credit with private financial institutions). Next, we discuss the options provided by international and regional financial institutions.

\section{A. Capital Controls}

Trivially, a country can shield itself from sudden changes in market sentiment by limiting its exposure to financial markets. Indeed, many observers (especially those skeptical of the virtues of free, unregulated markets), have pointed out the nexus between capital account openness and financial crises, and have suggested the introduction of taxes on capital transactions or direct capital controls as blunt but effective protection from sudden capital account reversals. ${ }^{12}$

${ }^{11}$ The traditional Bagehot view dictates that funds should be made available with certainty, at a penalty rate (relative to normal levels) to illiquid (but solvent) banks (see, Goodhart, 1995). It has to be noted, however, that liquidity assistance is typically collateralized by a well-defined list of eligible assets. On the other hand, although in principle bank supervisors should be able to assess ex ante the solvency of the bank, some authors argue that central banks should (and, in fact, do) make use of constructive ambiguity in situations in which the bank's solvency may be at stake (see Goodhart and Huang, 1999, and Freixas, 1999; and Cordella and Levy Yeyati, 2003, for a critical view).

12 These proposals include, among others, Tobin taxes on foreign exchange transactions, and Chilean-style taxes on short-term capital inflows. 
For the purpose of this paper, it is important to distinguish between the use of capital controls for crisis prevention and for crisis resolution. ${ }^{13}$ While, in the latter case, the incidence of controls is limited to the crisis period over which they are imposed, in the former, controls should be in place also in tranquil times, which inevitably magnifies their cost and gradually mines their effectiveness. ${ }^{14}$ Thus, the benefits of preventive capital controls in terms of financial stability should be weighted against their costs in terms of financial underdevelopment, reduced access to capital and, ultimately, disappointing growth.

This trade-off has been recently analyzed by Ranciere and others (2003), who find a robust empirical link between higher growth and higher propensity for crises across middle-income countries. The finding, which reconciles the negative view of financial liberalization as a source of macroeconomic instability with the positive view of liberalization as a growth driver, suggests that liberalization may yield faster growth at the expense of a higher crisis propensity. If so, rather than an effective insurance mechanism, controls appear to be an inefficient but ultimately tempting avenue for countries willing to embrace the growing opportunities offered by international financial markets but reluctant to expose themselves to abrupt changes in market perceptions that ultimately conspire against long-term growth.

\section{B. Self-Insurance}

An alternative avenue, increasingly used by emerging economies in recent years, is selfinsurance through the accumulation of international reserves. The motivation is straightforward: if international capital flows, far from offering a buffer against negative real shocks, behave procyclically or exhibit largely exogenous swings, it makes sense to generate a domestic pool of liquid foreign assets that can be used anticyclically to cope with sudden reversals in the capital account.

Much in the same way as individuals with limited and uncertain access to financial markets tend to increase their precautionary savings, a country shunned by international capital markets in times of distress tends to sit on a pile of cash. The evidence on this front is extensive. Irrespective of their exchange regime, most open emerging economies have kept increasingly high stocks of international reserves, especially since the latest stream of financial crises (see Table 1). Asian economies are the starkest example of this attitude, with reserves-to-GDP ratios of about 22 percent for Korea and China, and 35 percent for Malaysia. The phenomenon also extends to other regions. Overall, in our sample of 35 emerging markets, reserve holding as a fraction of GDP increased from 8.9 percent in 1992 to 18.1 percent in 2002. In the same period, reserves decreased from 3.2 percent and 0.6 percent to 2.1 and 0.3 percent of U.K. and U.S. GDP, respectively.

\footnotetext{
${ }^{13}$ For an evaluation of the effectiveness of Malaysian capital controls as a crisis resolution instrument, see Kaplan and Rodrik (2001).

14 The longer the period in which capital controls are in place, the higher the likelihood that agents find ways to circumvent them.
} 
Table 1. International Reserves

(As percentage of GDP)

\begin{tabular}{|c|c|c|}
\hline Country & 1992 & 2002 \\
\hline \multicolumn{3}{|l|}{ Emerging Markets } \\
\hline Algeria & 3.0 & 41.3 \\
\hline Argentina & 4.2 & 10.2 \\
\hline Brazil & 5.8 & 8.1 \\
\hline Bulgaria & 10.3 & 27.9 \\
\hline Chile & 19.8 & 22.0 \\
\hline China, & 4.0 & 22.5 \\
\hline Colombia & 13.2 & 12.7 \\
\hline Costa Rica & 11.7 & 8.7 \\
\hline Côte d'Ivoire & 0.1 & 15.9 \\
\hline Croatia & 1.7 & 25.8 \\
\hline Ecuador & 6.6 & 2.8 \\
\hline Egypt & 25.4 & 15.4 \\
\hline Hungary & 11.6 & 15.0 \\
\hline India & 2.0 & 13.5 \\
\hline Indonesia & 7.3 & 17.7 \\
\hline Israel & 7.7 & 22.8 \\
\hline Jordan & 14.6 & 42.4 \\
\hline Korea & 5.0 & 22.1 \\
\hline Lebanon & 26.3 & 41.6 \\
\hline Malaysia & 28.4 & 35.0 \\
\hline Mexico & 5.1 & 7.7 \\
\hline Morocco & 12.2 & 27.5 \\
\hline Nigeria & 3.4 & 15.9 \\
\hline Pakistan & 1.7 & 12.6 \\
\hline Panama & 7.3 & 9.5 \\
\hline Peru & 7.8 & 16.6 \\
\hline Philippines & 8.1 & 17.2 \\
\hline Poland & 4.6 & 14.6 \\
\hline Russia & n.a. & 12.7 \\
\hline South Africa & 0.8 & 5.3 \\
\hline Thailand & 18.3 & 30.0 \\
\hline Turkey & 3.7 & 14.5 \\
\hline Ukraine & 2.3 & 9.9 \\
\hline Uruguay & 3.8 & 6.2 \\
\hline Venezuela, Rep. Bol. de & 15.4 & 8.5 \\
\hline Average & 8.9 & 18.1 \\
\hline \multicolumn{3}{|l|}{ Industrial Countries } \\
\hline Australia & 3.5 & 4.7 \\
\hline Canada & 1.6 & 4.4 \\
\hline New Zealand & 7.3 & 5.5 \\
\hline Norway & 8.7 & 16.1 \\
\hline Switzerland & 13.0 & 13.9 \\
\hline United Kingdom & 3.2 & 2.1 \\
\hline United States & 0.6 & 0.3 \\
\hline Average & 5.4 & 6.7 \\
\hline
\end{tabular}

Sources: IMF, International Financial Statistics, and World Economic Outlook database. 
In principle, the annual cost of holding a unit of excess reserves should reflect the country's risk premium, as the government finances the purchase of excess reserves by issuing new debt (or, equivalently, by postponing the payment of outstanding debt), and stashes the proceeds in liquid investments (for example, U.S. treasury bills). ${ }^{15}$ While this back-of-theenvelope calculation overstates actual costs, as it does not take into account the contribution of reserve holdings to lower the country risk premium (paid on the full stock of debt), the self-insurance option may nonetheless entail substantial costs.

Some authors have proposed ways of improving on this self-insurance strategy. Caballero and Panageas (2004), for example, have suggested that reserves be invested partially in assets that are negatively correlated with country risk (as opposed to high-grade foreign currency assets). A similar proxy hedging strategy for the asset side of the government balance sheet in the case of commodity exporters consists of using derivatives in commodities (Caballero and Panageas, 2003). ${ }^{16}$ A more general way of insuring a country's debt against adverse macroeconomic developments is the indexation of foreign liabilities directly to the GDP (Borensztein and Mauro, 2003). To the extent that an appropriate hedging strategy reduces the size of the exposure in the event of an adverse shock, it would, in turn also reduce the amount of liquid foreign assets to be held as self-insurance.

The main obstacle faced by all these theoretically appealing initiatives is related to their cost. As in a standard insurance contract, a fairly priced hedge implies the payment of an insurance premium in all states in which the insurance is not utilized. In particular, it implies financial losses when commodity prices go up, or higher coupons in years of vigorous growth. This perfectly reasonable cost is, nonetheless, extremely hard to sell politically - a characteristic that does not make hedging any less desirable but limits its chances of being implemented in practice. In addition, in many cases commodity markets may not be liquid enough to hedge important shares of a country's liabilities at low cost.

In addition, the very motivation underlying reserve holdings suggests another potential shortcoming of the hedging variety of self-insurance. Given that the perfect hedge against liquidity runs for indebted emerging economies would be to long their own debt, the fact that they save liquid assets instead of reducing the stock of debt highlights the benefits of counting on liquidity, both to forestall a run and to dissuade prospective runners from running. A book of highly volatile derivatives may be less effective for these purposes.

\footnotetext{
15 Thus, it would have to pay an "annual fee" equivalent to the interest rate premium over the international risk-free rate. This rough estimation would not apply, however, if the country holds reserves in excess of the stock of public debt.

${ }^{16}$ This requires that a significant fraction of fiscal revenues comes from commodity exports, either through direct ownership of the production facility or through export taxes. Caballero and Panageas' argument for the use of copper futures in the case of Chile could be extended to Mexico (oil) or even Argentina (soybeans).
} 
Finally, there is another aspect of the self-insurance approach (in any of its varieties) that has received less attention. Self-fulfilling runs are, by definition, endogenous to the amount of insurance (in the limit, a perfectly insured country should be immune to a nonfundamental self-fulfilling liquidity run). ${ }^{17}$ If the probability of a crisis were a continuous function of insurance coverage, more insurance would reduce the ex ante probability of a run. This, in turn, would lower the optimal amount of insurance needed to face a run for a given ex ante probability - thereby converging to an optimal insurance coverage that balances insurance costs and crisis propensity. If so, the observed frequency of crises should reflect not only the distribution of external shocks faced by the country but also its level of self-insurance. As a result, it is extremely difficult to estimate the optimal amount of insurance based solely on the historical data on crisis propensity, as the latter is not independent of the former.

Moreover, real life examples are likely to be discontinuous. For simplicity, assume that there is a threshold stock of reserves such that holdings below that level are not a credible protection against runs, whereas holdings above that level reduce the probability of a crisis to zero. This leaves the country with two choices: full insurance (which entails a suboptimally large stock of reserves that is never used) or no insurance (in which case, the size of the stock is immaterial and it is optimally set at zero). By contrast, in this simplified setting, an insurer with the capacity to produce liquidity on demand could offer full insurance at zero cost (since in this case insurance money would never be required). ${ }^{18}$ This explains why central banks are the providers of liquidity insurance in domestic currencies, and why the provision of liquidity in foreign currencies could effectively be delegated to an IFI that can tap international markets (or national treasuries) when needed. Note that this efficiency gain with respect to self-insurance would add to the gains from risk pooling that are typically highlighted in this regard.

All this being said, given the substantial and persistent costs of financial crises and the absence of efficient market-based alternatives or customized official facilities, self-insurance appears to be a dependable - albeit costly_option, for countries facing increasing international integration, to reduce the volatility associated with portfolio flows without having to rely on belated international rescue packages.

${ }^{17}$ Unlike in a standard insurance contract, expected insurance outlays (and hence fair insurance costs) would be determined here by the amount of insurance purchased. Note that the standard assumption of an exogenously given probability of capital account reversals is at odds with their non-fundamental nature.

${ }^{18}$ This is due to the fact that, if crises are purely of the self-fulfilling type, there is no fundamental risk, so that the availability of insurance eliminates its need. 


\section{Private Insurance}

One alternative to self-insurance is the outsourcing of the insurance function to a private international agency that, in its simplest form, can be conceived as a contract between a consortium of international banks and the treasury.

Practical examples are hard to find. The closest experiment is the contingent repo contract signed by the Argentine central bank and a consortium of foreign banks in the late 1990s, under which the former was allowed to withdraw funds, in the event of a crisis, from a threemonth, renewable credit line collateralized by dollar-denominated government bonds. ${ }^{19}$ While the insurance cost was certainly small compared with that of holding reserves, the appeal of this type of solution appears to be (as it was in the Argentine case) subject to important qualifications.

First, the fact that the same large international players are likely to be on both sides of the contract creates a potential agency problem. More precisely, it is difficult to envisage a way in which the insurance contract can credibly prevent insuring banks, as perceived sovereign risk mounts, from hedging by shorting the same government bonds used as collateral, thus accelerating the collapse of bond prices. ${ }^{20}$ Second, the scope for the insurer to diversify highly correlated emerging market risk would be narrow, limiting the potential size of the coverage and increasing its costs. Alternatively, there may be a reverse moral hazard problem, as insurers are lured into taking on more risk than they can reasonably handle.

These factors help explain why the coverage under the Argentine contract was relatively limited, and why execution was delayed until August 2001, when the liquidity run was well under way, and in connection with an agreement with the IMF that drove up, albeit momentarily, the price of bonds. ${ }^{21}$ At any rate, this experience does not bode well for more ambitious market-based country insurance arrangements.

${ }^{19}$ For a thorough description and discussion of this arrangement, see Broda and Levy Yeyati (2003).

${ }^{20}$ The margin call also adds to this negative feedback. Note that although the insuring banks know that by hedging they increase the probability that the repo is activated, they face a coordination problem as the negative impact of their actions is diluted in the aggregate while the benefits from hedging accrue entirely to individual banks. Thus, the argument implicitly assumes that no individual bank will be willing or able to insure the country single-handedly.

${ }^{21}$ The contract ultimately provided a meager US $\$ 1.77$ billion (out of US $\$ 4.75$ billion available at the beginning of 2001). Moreover, owing to the ongoing liquidity run, the decline in the price of the bonds used as collateral implied a reduction in the size of the line, which dropped to US\$1.35 billion at the first 3-month renewal (generating a financing gap for the difference). 


\section{IMF-Led Packages}

The main distinctive characteristic of existing IMF facilities is the attachment of ex post conditionality to foster corrective action, at the cost of reducing the predictability of IMF assistance. Approval is subject to reaching an agreement on a set of policies, and disbursements require compliance with the latter. ${ }^{22}$ As a result, the amount and timing of assistance is not automatic as the precise conditions of IMF disbursement cannot be clearly defined ex ante.

The insistence on ex post conditionality and the lack of automaticity in the IMF's disbursements reflect the fact that IMF facilities are designed to help a country deal with crises that are rooted in weak fundamentals. IMF assistance should thus provide a country with just enough funds to overcome its balance of payment needs while it takes the steps needed to strengthen fundamentals. In line with this, IMF programs are expected to be "tough" so that only countries seriously committed to redressing their imbalances have access. The corollary of such toughness is that (most) emerging countries prefer to incur substantial costs in private markets and turn to the Fund only when all other sources of financing are exhausted. ${ }^{23}$

To illustrate the previous point, in Figure 1, for a sample of emerging economies, we compute EMBI spreads in the 12 months preceding the date in which country authorities announced their intention to negotiate with the Fund. ${ }^{24}$ These spreads should reflect the marginal financing cost faced by the country at the time, so that the difference between them and the (much lower) spread charged by IMF facilities could be taken as a proxy for the cost (as perceived by the government) of subscribing to an IMF program. ${ }^{25}$ The fact that it has not been uncommon for countries to postpone a request for an IMF program until EMBI spreads went well above 1,000 bps suggests that this cost may be substantial. If so, politically costly

${ }^{22}$ The IMF will lend to a country only if the IMF Executive Board approves a letter of intent in which the country lays down the steps that it is willing to undertake to redress the macroeconomic imbalances that created the balance of payments need. Disbursement, is conditional on the implementation of the policies agreed on in the letter of intent.

${ }^{23}$ The reluctance to request a Fund program may also reflect a signaling problem: approaching the Fund may be perceived as a sign of hidden weakness, much in the same way as banks that come to the central bank's liquidity window may be stigmatized by the market.

${ }^{24}$ As reported in the news.

${ }^{25}$ The basic rate of charge on Stand-by Arrangements (SBAs) is about 100 basis points (bps) over the risk-free rate. A surcharge of 100 bps is applied for credit over 200 percent of a country's quota in the IMF, while programs over 300 percent of the quota command a surcharge of $200 \mathrm{bps}$. Higher surcharges are applied to funds drawn from the Supplemental Reserve Facility (SRF), starting from 300 bps and increasing by 50 bps after one year and each subsequent six months up to a maximum of $500 \mathrm{bps}$. 
Figure 1. EMBI Spreads in the 12-month Preceding Request for an IMF Program

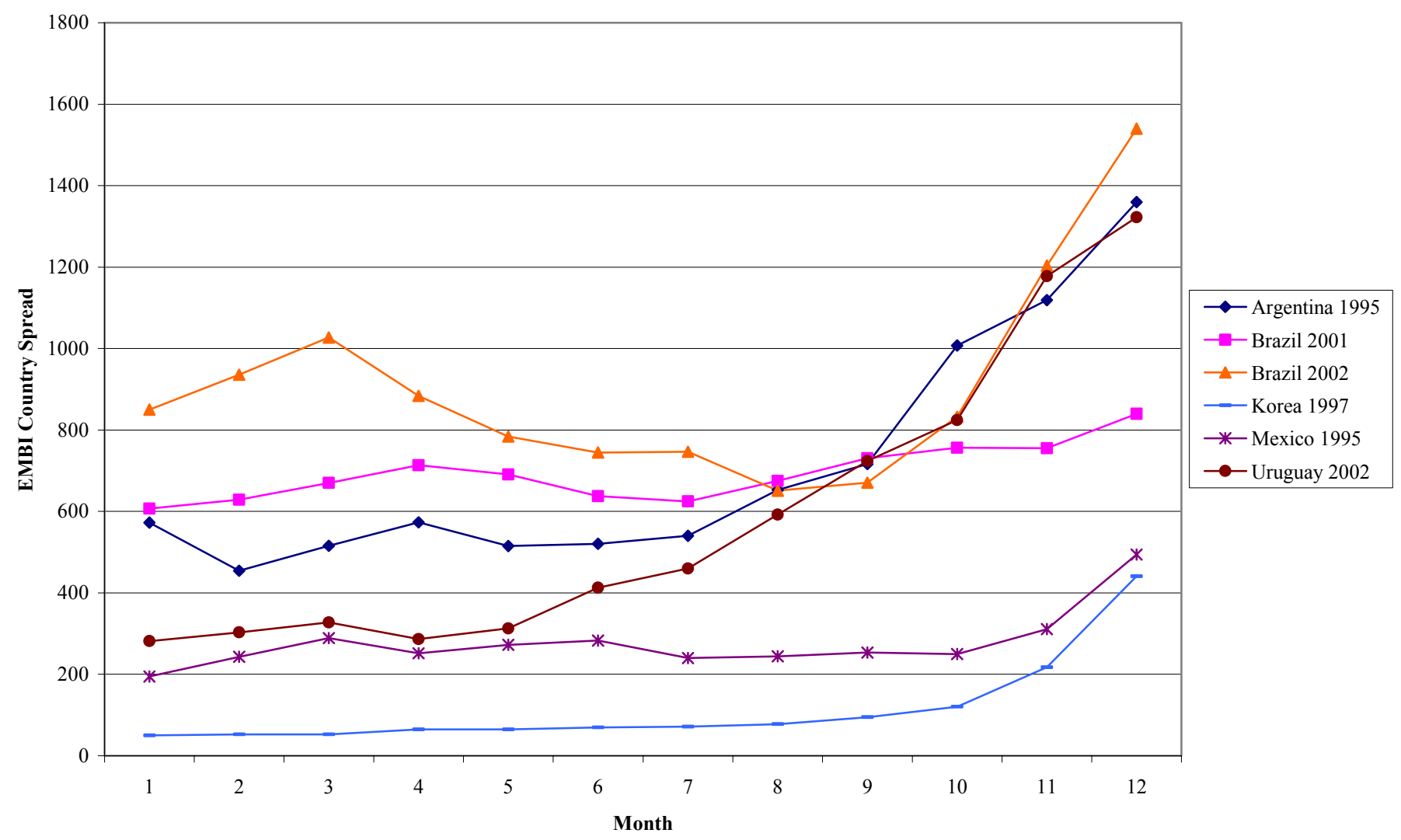

Source: IMF staff estimates; and J.P. Morgan. 
conditionality, by making countries less willing to apply for IMF assistance before it is too late, conspires against the contribution of Fund-led packages to preventing liquidity runs. ${ }^{26}$

The growing understanding that many of the recent crises may have been triggered by nonfundamental reasons has highlighted these shortcomings. Partly in response to this, and to the demand by member countries to devise an ad hoc facility that addresses sudden liquidity runs, ${ }^{27}$ the IMF has made efforts to soften its requirements and expedite the approval process in specific cases. A good example of this new approach was the fast renewal of the line of credit to Brazil in 2003 and 2004. The program was indeed portrayed as insurance against liquidity runs, aimed at gearing market expectations toward a good equilibrium with reasonable private refinancing costs. It is important to note, however, that in this case the IMF could respond so effectively largely because the country was already "prequalified" by its compliance with an ongoing Fund program. The course of events could have been different had the IMF been forced to start a negotiation with the Brazilian authorities from scratch at the very moment that market confidence waned.

The concept of prequalification also played a key role in the CCL initiative, launched in 1999 by the IMF as a tool to help countries with sound fundamentals to cope with liquidity crises. The facility, however, was never used and was discontinued in November 2003. For our purposes, it is instructive to revisit the causes of such a disappointing result.

The CCL was designed to "overcome the exceptional balance of payment financing needs that can arise from a sudden and disruptive loss of market confidence due to contagion, that is, circumstances that are largely beyond the member's control." ${ }^{28}$ However, in order to qualify for the CCL, a country had to make an explicit request to the IMF that had to be approved by the Board. Since no request for CCL prequalification was made during the first year of the facility, in November 2000 the CCL was modified with the view of making it more appealing, to no avail. ${ }^{29}$

Many factors may have contributed to the CCL failure. Among these, observers have highlighted the "entry" and "exit" problems, and the lack of automaticity of disbursement. The entry problem refers to the fact that an otherwise solvent country's request of eligibility

${ }^{26}$ For a discussion of IMF conditionality and its costs, see Goldstein (2001).

${ }^{27}$ Henrique de Campos Meirelles, Governor of Brazil's central bank, said at the 2004 IMFWorld Bank annual meetings, "We would like to see a facility that prevents crises, particularly when they are caused by changes in market sentiment that have nothing to do with emerging markets in general" (Dow Jones Capital Markets Report, October 3, 2004).

${ }^{28}$ IMF Press Release No. 99/14, April 25, 1999.

${ }^{29}$ In the revision, initial monitoring arrangements were streamlined, mid-term reviews were simplified, and the rate of charge and the commitment fee were reduced. See IMF (2003) for a detailed discussion. 
could be perceived by the market as a signal of weakness. Since CCL eligibility was contingent on IMF Board approval (hence, uncertain) and coverage was too limited to fully insure the country, governments may have been disheartened by the possibility that a mere request (let alone a rejected one) could be interpreted by the market as a warning.

The exit problem, in turn, concerns essentially two situations. On the one hand, a declaration of ineligibility (including countries that cease to be eligible because of a deterioration of fundamentals) could have had a deleterious impact on the market's perception of the country's solvency. On the other hand, a country's voluntary decision not to renew the CCL commitment could have been interpreted as a signal of macroeconomic weakness rather than strength. If to these signaling problems we add the fact that the conditionality attached to the CCL was not too dissimilar from that of a standard IMF program, and that a commitment fee was charged to the country once the prequalification process was successfully finalized, it is not surprising that member countries did not find the CCL attractive.

Taking stock of this experience, it is important to note that the entry and (to some extent) the exit problems depend on the country's need to make the first move to access the facility. These problems would be eliminated if eligibility criteria were made automatic. ${ }^{30}$

\section{E. Regional Swap Agreements ${ }^{31}$}

An additional form of insurance against sudden liquidity shortages comes from what could be broadly defined as regional swap agreements under which participating countries can borrow from other members on very short notice for short periods of time. Among the agreements including emerging economies, we can count the North American swap agreement and the Chiang Mai initiative (CMI).

The first, arranged in April 1994 among Canada, Mexico and the United States, provides 90-day renewable collateralized loans. The second, launched in May 2000 by the ten ASEAN members plus China, Japan, and Korea, involves bilateral (one- or two-way) currency swap arrangements for an estimated total of nearly $\$ 30$ billion. $^{32}$

These agreements present clear similarities with the type of facility proposed in this paper. They offer immediate short-term liquidity support, and avoid the hedging problems that would arise in the case of a contingent credit line with private institutions. However, their

\footnotetext{
${ }^{30}$ However, automaticity would not fully avoid the impact of changing fundamentals on borrowing costs, as countries get closer or further away from eligibility. We come back to this below.

${ }^{31}$ This section is based Huang (2004).

${ }^{32}$ While currency swaps between ASEAN countries date back to 1977 , they were rarely used due to their small volumes. The CMI represented a substantial increase in the amounts involved.
} 
(yet untested) effectiveness in preventing liquidity runs may be critically limited by the fact that access to the swap is not automatic: members have the choice to turn down a request for funds at their discretion. Size also appears to be a problem, although the initiative has been growing steadily and provides liquidity comparable to that under a Fund program.

Interestingly, both the North American arrangement and the CMI assign the IMF the surveillance role, the former by requesting the Fund an economic assessment of the requesting country, the latter by releasing 90 percent of the swap only after the country has entered program negotiations with the Fund - although it appears that an actual agreement is not a precondition for drawing.

While the efficacy of these regional arrangements for emerging economies depends notably on the presence of large countries with access to liquidity, they are the closest to the liquidity facility proposed here that the international financial architecture currently provides. Indeed, they appear to have developed, to a large extent, to make up for the lack of an international liquidity facility such as the one discussed below.

\section{A New COUNTRY InSURANCE FACILITY}

The country insurance facility (CIF) that we propose here amounts essentially to an interest rate insurance that guarantees automatic access to a line of credit at a prefixed rate, if the borrowing country complies ex ante with a number of verifiable conditions. ${ }^{33}$ Whenever a liquidity run pushes borrowing costs above the CIF interest rate, an eligible country may turn to the insurer as an alternative financing source, avoiding the need to validate temporarily high interest rates that may have permanent negative effects on debt sustainability.

The objective of the CIF is to minimize the rollover risk that is at the root of self-fulfilling crises, without inducing an unwarranted use of the facility. Specifically, the CIF should reduce both the uncertainty surrounding the timely access to finance and the associated financing costs, while preserving the incentives to resort to private markets under normal circumstances. Indeed, the single distinctive characteristic of a CIF relative to a standard Fund program is its predictability: access to liquidity assistance should be automatic subject to observable ex ante conditions.

To make the CIF operational one should carefully define the eligibility criteria, the prefixed interest rate to be charged, and the size of the credit line. Moreover, it is also crucial to characterize clearly the procedures to be followed after the CIF is tapped, to ensure that the solvency and seniority of the CIF is not compromised. These procedures should cover, among other things, the maturity of the credit line and the conditions for rollover, as well as

\footnotetext{
${ }^{33}$ Note that, while central banks typically do not impose conditions on access to a standing liquidity facility, eligibility criteria are implicit in the prudential requirements that banks have to comply with on a continuous basis and in the list of eligible assets that typically collateralize liquidity assistance.
} 
the restrictions on new debt issuance to avoid dilution of outstanding CIF claims. We address each of these issues in more detail below.

\section{A. Eligibility Criteria}

Eligibility criteria should be chosen to meet two basic principles that are key to the appeal and the feasibility of the CIF. On the one hand, they have to be readily observable: at no point in time should there be any doubt about whether or not a country is eligible. ${ }^{34}$ On the other hand, the eligibility criteria should be aimed at ensuring the solvency of the CIF, which requires, essentially, the solvency of the country at the prevailing CIF ceiling rates.

It is natural, then, that conditions should focus primarily on the debt, with the view of ensuring sustainability in a reasonably adverse scenario. By this, we mean that the country should be able to repay the CIF and refinance its obligations with private lenders in the event of a persistent adverse shock, provided that borrowing costs are kept within reasonable bounds. By contrast, eligibility conditions based on the market interest rates faced by the country would be subject to multiple equilibria problems, as a high country-risk premium would move an eligible (ineligible) country closer to (further away from) the threshold level, increasing country risk in the process. ${ }^{35}$

As a general principle, the eligibility criteria should be tight enough to ensure that only countries with a sustainable level of debt apply, but not so tight that access will be denied to virtually all countries prone to confidence crises. Furthermore, compliance criteria should not be so burdensome that countries prefer to rely on existing IMF facilities.

The quantitative definition of these requires a trade off between accuracy and simplicity. On theoretical grounds, a Value at Risk (V@R) approach would probably be the best avenue to determine eligibility thresholds. However, it would entail country- and time-specific conditions that, when associated with the complexity of V@R models (and their untested extrapolation to the balance sheet of a sovereign government), are likely to make the final criteria highly questionable, conspiring against the transparency of the whole scheme. For this reason, we believe that the eligibility criteria, while faithful to the nature of the V@R analysis, should follow a simpler formula applicable to all countries at all times. ${ }^{36}$

\footnotetext{
${ }^{34}$ Naturally, eligibility in the near future will still be influenced by sudden unexpected changes in economic conditions and will be subject to a degree of uncertainty in borderline cases. We will come back to this important point later on.

${ }^{35}$ Note that the Maastricht criteria included conditions on both solvency and interest rate convergence, aimed at reducing the perception of an implicit regional LLR to mitigate free riding. The CIF, by contrast, is intended to play a LLR role, inducing interest rate convergence as a result.

${ }^{36}$ It follows that, in order to be eligible, countries should be willing to provide detailed and reliable information on a few relevant variables on a continuous basis.
} 
Such a formula cannot ignore the different risk profile of debt denominated in the domestic currency (peso, for short) and in a foreign currency (dollar, for short). ${ }^{37}$ Since swings in the real exchange rate may dramatically affect (and, in particular, increase) the debt-to-GDP ratio over the lifetime of a CIF loan, dollar debt should carry a larger weight. A simple exercise helps illustrate this point. Table 2 reports the 95 and 99 percentiles of a crude approximation to the distribution of real exchange rate changes in emerging markets (EMs). The distribution was obtained by pooling annual changes in the real peso-dollar exchange rate for a sample of 21 EMs during 1990-2003. ${ }^{38}$ As can be seen in Table 2, setting the probability level at 99 percent, the worst-case scenario would entail a real devaluation of around 60 percent, which would translate into a weight for the dollar debt of 1.60.

Table 2. Twelve-month Real Exchange Rate Changes in Emerging Economies

\begin{tabular}{|c|c|c|c|}
\hline & & RER1 1/ & RER2 2/ \\
\hline \multirow[t]{2}{*}{ Percentile } & 95 & 0.257 & 0.234 \\
\hline & 99 & 0.643 & 0.581 \\
\hline Average & & 0.005 & 0.004 \\
\hline Standard deviation & & 0.174 & 0.154 \\
\hline Observations & & 2807 & 2807 \\
\hline
\end{tabular}

Source: Authors' calculations using data from IMF, International Financial Statistics, for the countries included in J.P. Morgan's EMBI Global Portfolio.

$1 /$ Nominal exchange rate deflated by the WPI.

2/ Nominal exchange rate deflated by the simple average of the CPI and the WPI.

Whatever methods are ultimately chosen to compute solvency thresholds, the basic principles guiding the choice should be transparent: a country eligible to borrow from the facility should have a debt-to-GDP ratio low enough that, at the prefixed CIF rate, and without major changes in the current fiscal stance, its debt dynamics are sustainable in the long run. Taking the interest rate charged on CIF loans as given, there are two basic debt-related dimensions that one may want to consider as part of this set of preconditions: the debt-to-GDP ratio, and the fiscal deficit.

${ }^{37}$ Debt maturity also deserves specific treatment; see below. Note that the data and the methodology used by the CIF to assess the eligibility criteria should be publicly disclosed. In this respect, it is crucial that the Special Data Dissemination Standard (SDDS) collect data on the currency and the maturity composition of public debt. At the moment, only very few countries provide such figures.

${ }^{38}$ Nominal exchange rates were deflated, alternatively, by the wholesale price index (WPI), and the simple average of the CPI and the WPI, to proxy for the GDP deflator. 
The first one is essential to evaluating long-term sustainability. Given existing debt stocks, the fiscal deficit is critical in turn to assessing whether current policies are conducive to sustainable or explosive debt dynamics in the future. From a practical perspective, a large fiscal deficit that leads to debt accumulation would indicate that the entry debt level might no longer be sustainable in the next period, casting doubt on a country's capacity to repay the CIF. From an economic perspective, it would signal that the rise in the country risk premium, is due to the presence of structural fiscal problems, rather than to a temporary confidence crisis. Such fiscal problems would call for deeper reforms that would be best addressed by a standard Fund program.

Inevitably, both debt and deficit (and, as a result, eligibility) would be subject to cyclical fluctuations. Theoretically, this problem could be mitigated by the use of cyclically adjusted measures, albeit at the expense of transparency. For this reason, we tend to favor, as a compromise between prudence and flexibility, the use of cruder but simpler measures. For example, the condition on the debt stock could place a limit on an $n$-year moving average of the debt-to-GDP ratio. ${ }^{39}$ In turn, the deficit limit could be set large enough to let automatic stabilizers work, but low enough to prevent unduly expansionary policies: a Maastrichtinspired rule, by which the deficit cannot exceed 3 percent in each of the three preceding years, may be a useful reference.

The limited, short-term nature of the facility introduces a third relevant dimension. In principle, whenever an eligible country is hit by a confidence crisis that raises its borrowing costs above the CIF interest rate, it would have the option of borrowing from the CIF to meet the service of its outstanding debt. However, much as in the case of Fund programs, the fact that a country is eligible to limited CIF assistance does not impose a cap on borrowing costs in private markets, since default on private obligations (as opposed to the CIF) is always possible if short-term financing needs exceed the size of the CIF credit line. Thus, the efficacy of the CIF will depend crucially on the degree of insurance coverage, defined as the ratio of the size of the CIF over the public sector financing requirements over the duration of the CIF loan. In order for the scheme to preempt liquidity runs effectively, the size of the CIF loan should be sufficient to meet the largest part of the country's short-term financing requirements. It follows that, given the size of the CIF, eligibility conditions should impose an additional subceiling on the short-term debt-to-GDP ratio (defined as the stock of debt coming to maturity over the life of the CIF loan), with a view to setting insurance coverage close to 100 percent.

A concrete example may help put all these conditions in perspective. Assume that eligibility to the CIF is subject to the following Maastricht-inspired criteria: (i) an average public (localcurrency-denominated) debt-to-GDP ratio over the last three years below 60 percent (where

${ }^{39}$ A related operational issue is the way in which international reserves (and off-balancesheet items) should enter into the computation of debt ratios. 
a unit of foreign-currency-denominated debt is weighted as 1.6 times a unit of localcurrency-denominated debt), and (ii) a fiscal deficit below 3 percent in each of the preceding three years. $^{40}$

It is interesting to examine what countries would have been eligible under these criteria and whether there were instances in which eligible countries were charged high-risk premiums that eventually led to an unsustainable debt spiral (see Table 3). ${ }^{41}$ The evidence presented in Table 4 suggests that only a few Ems would have been eligible in the past decade, and that there are a few instances in which eligible countries were charged high spreads (presumably above the one to be charged by the CIF), such as Korea and Thailand at the onset of the Asian crisis. $^{42}$

The fact that few countries (generally considered to exhibit solid fundamentals) would have been eligible is an indication that the facility, while automatic, would not have entailed a dangerous move toward unwarranted leniency. On the other hand, it is reasonable to assume that, had the facility been in place, more countries might have had the incentive to adopt policies conducive to solvency and eligibility.

\section{B. Interest Rate}

A model for the determination of CIF charges in line with the objective of minimizing rollover risk while limiting undue use of the facility is again provided by standard lender of last resort practices. Emulating the concept of a penalty rate relative to precrisis levels, the CIF interest rate could be set at a premium over the risk-free rate corresponding to the currency and duration of the credit line (as is customary when computing charges in IFI nonconcessional loans).

Intuitively, the risk-free rate would capture changes in global liquidity that affect the cost of capital irrespective of country-specific risk. The use of alternative reference rates (for example, a weighted average of emerging market rates as measured by the EMBI spread) could instead be problematic: liquidity runs that affect many emerging markets in the index would dramatically increase the cost of the facility and thus make the insurance less effective in shielding a country from a crisis - in times in which insurance is most needed.

${ }^{40}$ In principle, the CIF (particularly, its premium and size) could be more generous for countries that overcomply with the eligibility criteria (and thus, that are less likely to present a solvency issue in the future), thereby introducing further incentives for countries to reduce indebtedness or bring down fiscal deficits beyond what is required to be eligible.

${ }^{41}$ Since we do not have data on the currency composition of foreign debt, we arbitrarily assumed that all domestic (foreign) debt is in pesos (dollars). In addition, since we do not have data on debt maturity, we ignore this criterion for the purpose of the exercise.

${ }^{42}$ In addition, one could conjecture that the existence of the CIF may have helped Chile avoid the preventive monetary tightening in 1998-1999, in response to the Asian crisis. 


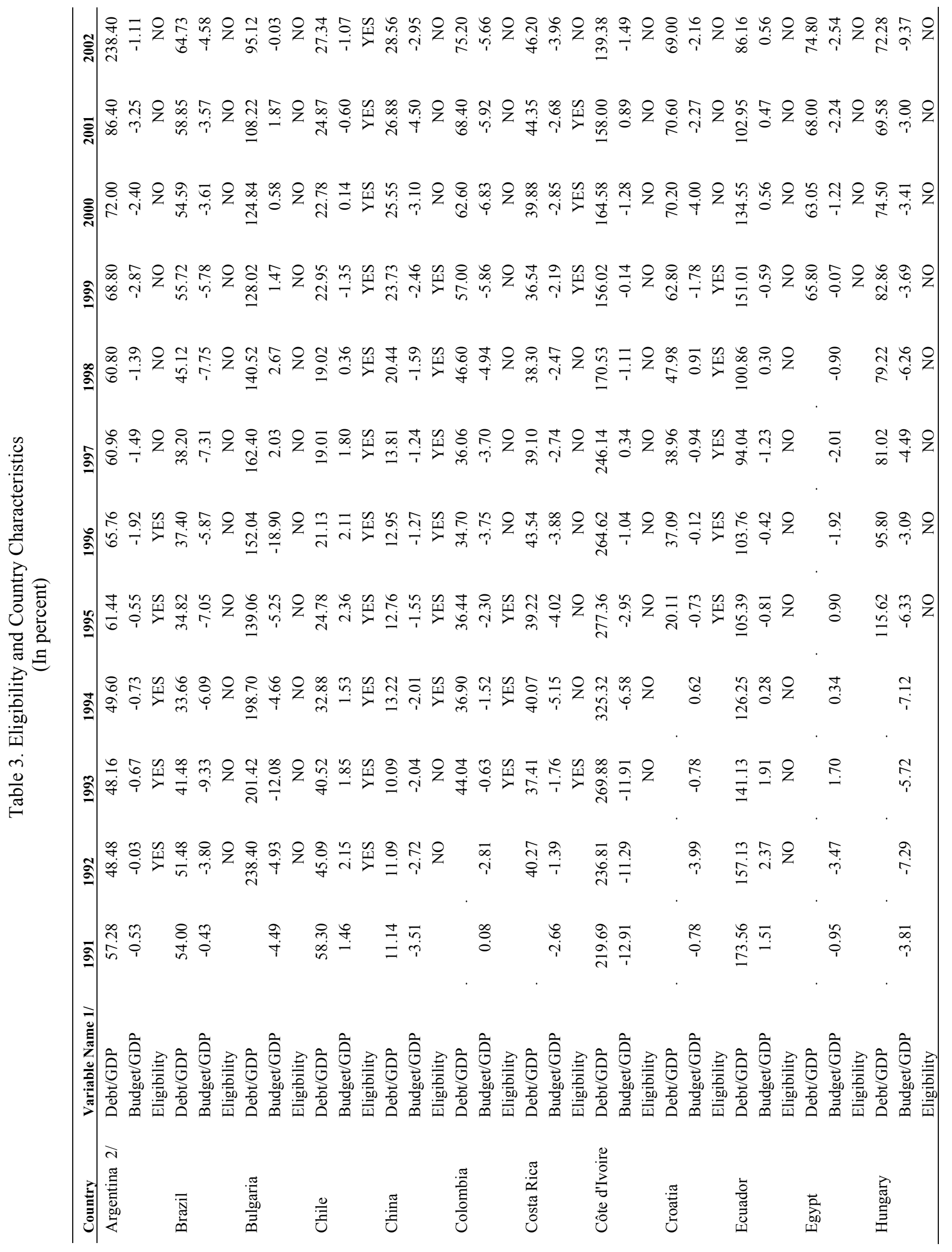




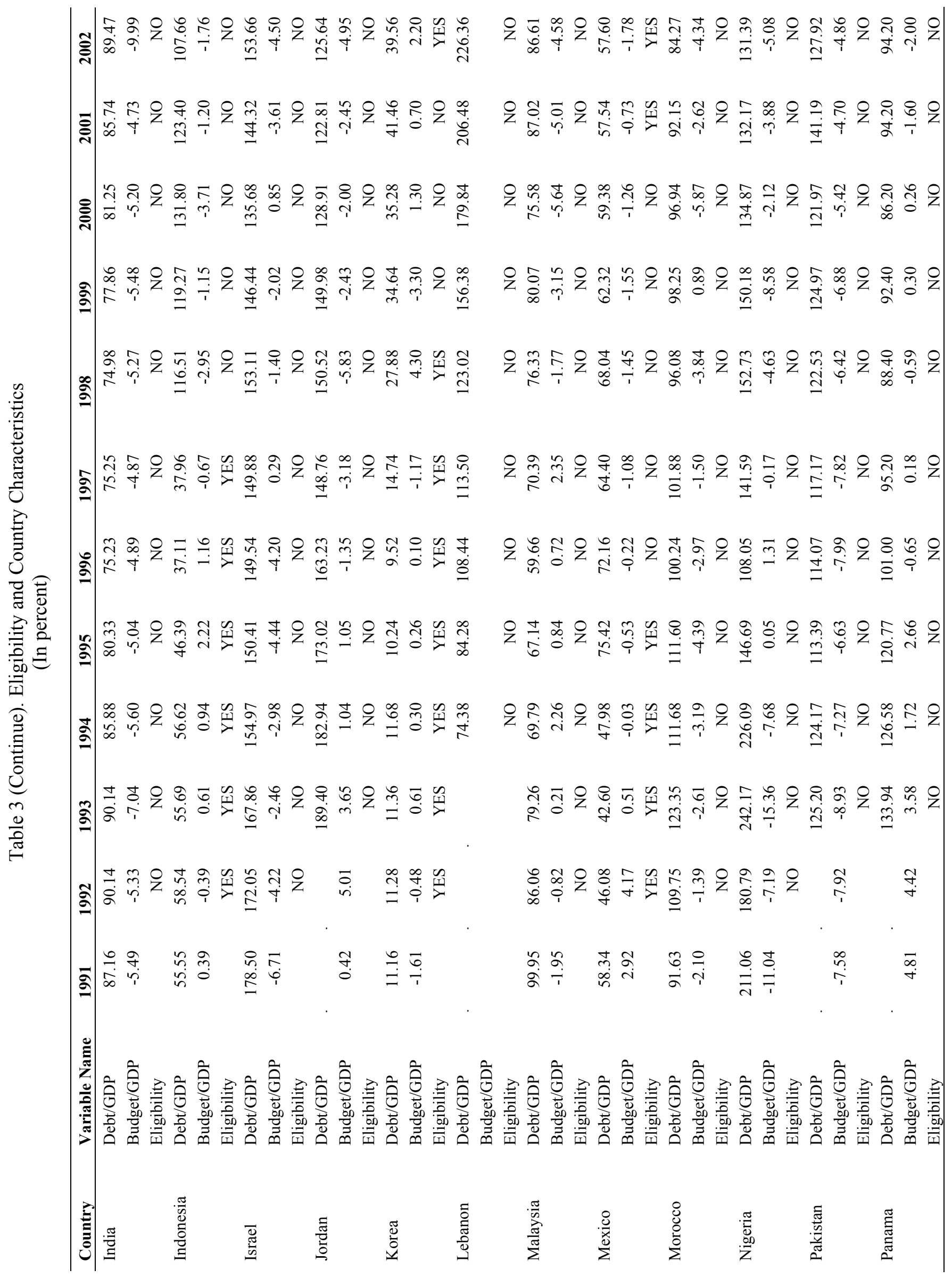




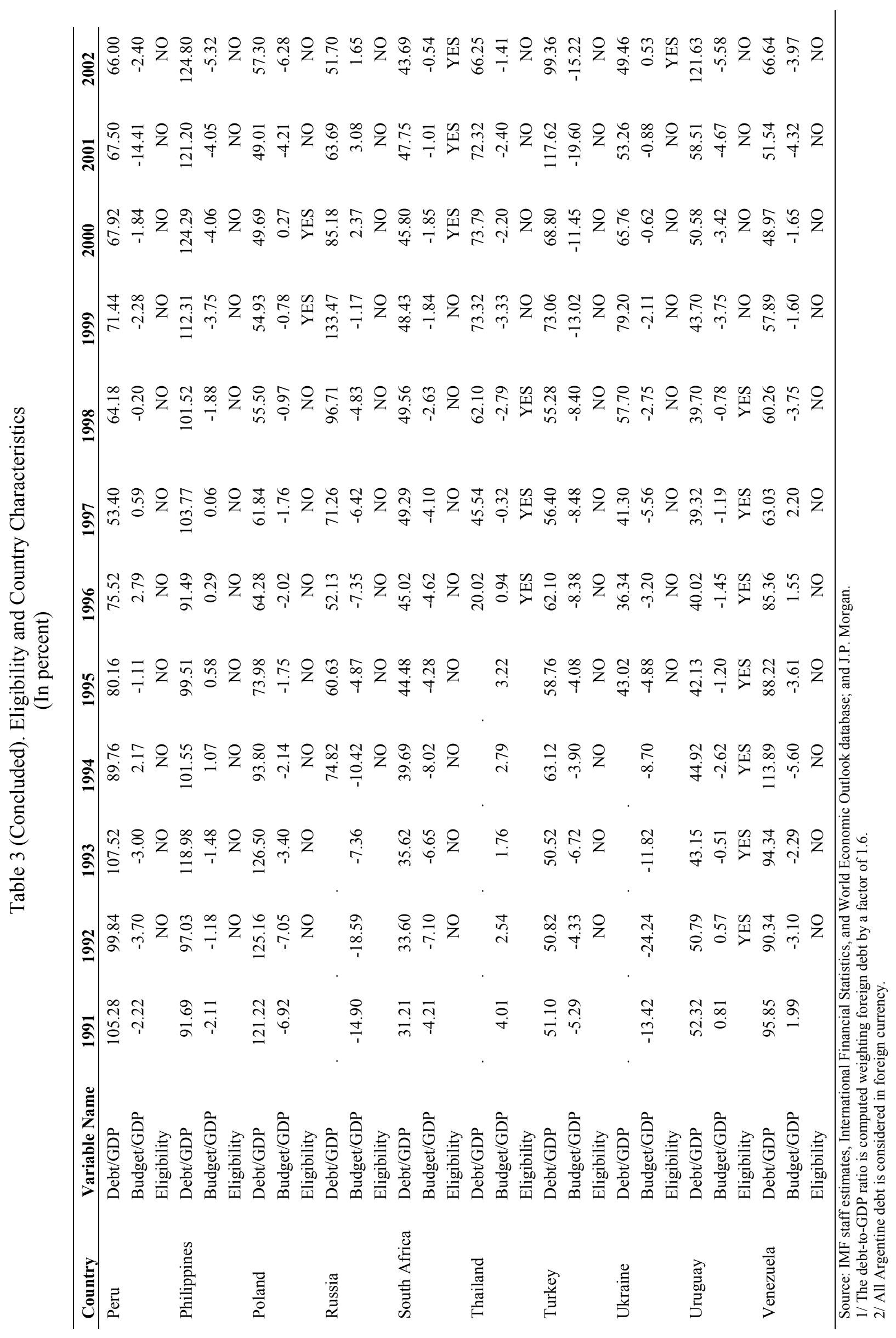


Table 4. Eligibility Criteria and EMBI Country Spreads

\begin{tabular}{|c|c|c|c|c|c|c|c|c|c|c|c|}
\hline Country & 1992 & 1993 & 1994 & 1995 & 1996 & 1997 & 1998 & 1999 & 2000 & 2001 & 2002 \\
\hline Argentina & & 264 & 505 & 934 & 504 & 290 & 464 & 577 & 571 & 1361 & 3926 \\
\hline Brazil & & & 810 & 916 & 556 & 364 & 673 & 872 & 646 & 793 & 1204 \\
\hline Bulgaria & & & 1307 & 1311 & 1101 & 616 & 592 & 651 & 563 & 499 & 291 \\
\hline Chile & & & & & & & & 173 & 196 & 197 & 184 \\
\hline \multicolumn{12}{|l|}{ China } \\
\hline Colombia & & & & & & 186 & 484 & 591 & 671 & 577 & 655 \\
\hline \multicolumn{12}{|l|}{ Costa Rica } \\
\hline Cote d'Ivoire & & & & & & & 921 & 1050 & 1660 & 2163 & 1998 \\
\hline Croatia & & & & & 231 & 214 & 507 & 627 & 376 & 241 & 175 \\
\hline Ecuador & & & & 1005 & 785 & 498 & 712 & 1521 & 1761 & 1345 & 1385 \\
\hline Egypt & & & & & & & & & & 427 & 392 \\
\hline Hungary & & & & & & & & 139 & 104 & 69 & 92 \\
\hline \multicolumn{12}{|l|}{ India } \\
\hline \multicolumn{12}{|l|}{ Indonesia } \\
\hline \multicolumn{12}{|l|}{ Israel } \\
\hline \multicolumn{12}{|l|}{ Jordan } \\
\hline Korea & & 89 & 102 & 78 & 66 & 116 & 501 & 226 & 212 & 224 & 142 \\
\hline Lebanon & & & & & & & 250 & 239 & 201 & 503 & 932 \\
\hline Malaysia & & & & & 60 & 92 & 507 & 320 & 216 & 238 & 185 \\
\hline Mexico & & 157 & 250 & 514 & 343 & 224 & 319 & 347 & 243 & 285 & 274 \\
\hline Morocco & & & & & & 436 & 637 & 653 & 464 & 527 & 485 \\
\hline Nigeria & & 826 & 1383 & 1416 & 727 & 415 & 661 & 752 & 1081 & 791 & 803 \\
\hline Pakistan & & & & & & & & & & 1533 & 689 \\
\hline Panama & & & & & 450 & 288 & 414 & 466 & 434 & 433 & 423 \\
\hline Peru & & & & & & 400 & 572 & 600 & 562 & 643 & 602 \\
\hline Philippines & & & & & & 296 & 404 & 343 & 507 & 581 & 433 \\
\hline Poland & & & 477 & 474 & 194 & 140 & 190 & 201 & 196 & 178 & 168 \\
\hline Russia & & & & & & 658 & 2433 & 3828 & 1344 & 921 & 520 \\
\hline South Africa & & & 237 & 245 & 144 & 132 & 413 & 424 & 333 & 306 & 266 \\
\hline Thailand & & & & & & 202 & 409 & 207 & 161 & 162 & 105 \\
\hline Turkey & & & & & 245 & 222 & 550 & 587 & 537 & 867 & 717 \\
\hline Ukraine & & & & & & & & & 1785 & 1685 & 717 \\
\hline Uruguay & & & & & & & & & & 289 & 931 \\
\hline Venezuela & & 442 & 991 & 1227 & 635 & 298 & 759 & 849 & 721 & 733 & 808 \\
\hline
\end{tabular}

Source: IMF Staff estimates, International Financial Statistics, and World Economic Outlook; and J.P. Morgan.

1/ Shaded cells denote years in which the country was eligible for the CIF. Eligible criteria used in this example are (i) average domestic-currency debt-to-GDP ratio over the preceding three periods below 50 percent (where 1 unit of foreign-currency debt is weighted as 1.6 units of domestic-currency debt); and (ii) fiscal deficit in the three preceding periods below 3 percent. We assume that all external (domestic) debt is denominated in foreign (domestic) currency. 
As noted, the premium should be set low enough so as not to compromise the country's repayment capacity, and high enough to prevent the abuse of the facility and to maximize the country's efforts to get back on its feet and regain access to private markets at reasonable rates. One possible compromise between these different objectives consists of setting the CIF surcharge equal to $300 \mathrm{bps}$ (the surcharge on an SRF during the first year), and applying a 50 bps increase (as in the SRF case) if extended for another six months (see below).

A remaining question concerns the margin for a limited CIF to help countries regaining access to voluntary capital markets within the life of CIF assistance. While we think that, in the presence of a pure liquidity run, this is likely to be the case, one cannot rule out the possibility that confidence does not rebound (and the risk premium does not decline) even after the country taps the CIF. In these situations, however, the CIF would still play a positive role, smoothing out the transition to a standard IMF program.

\section{Duration}

The underlying assumption behind the establishment of a CIF is the presence of (presumably short-lived) self-fulfilling liquidity runs. It follows, then, that CIF loans should cope with liquidity shortages that, absent deeper structural problems, may be quickly reverted, or averted altogether by the sole existence of the facility. Specifically, loans should be short term, aimed at covering the country's financing needs over a period of, say, one year. If the liquidity run persists after that period, one may safely presume it to be rooted in more fundamental problems, which would be better tackled by a standard Fund program.

In this case, the CIF could be compared with the first (automatic) stage of central bank assistance, which sometimes precedes more serious central bank involvement in the event liquidity problems prove to be deeper rooted. Similarly, the CIF should be seen as strictly complementary to existing IMF arrangements.

One last point concerns the option to renew the CIF loan. Again, striking the right balance between credibility and prudence will necessarily involve some arbitrariness. Too short a loan may leave open the possibility of a new run as the loan approaches maturity. Long loans may induce excessive reliance on the CIF and may detract from the authorities' incentives to take actions aiming at restoring confidence. One alternative, among many others, would be to set the duration of loans at six-months (renewable, at a slightly higher rate, for another six months), so that the CIF represents a shorter alternative to the SRF (currently the IMF facility that provides the shortest-term loans). ${ }^{43}$

\footnotetext{
43 The SRF offers one-year loans renewable for a subsequent one and a half years at a rising cost (50 bps increase every six months).
} 


\section{Size}

It has been argued before that small Fund programs may ultimately be counterproductive, as unconvinced investors rapidly exhaust available resources in anticipation that they will be insufficient to avoid default (Zettlemeyer, 2000). The same concerns apply even more starkly to the CIF: a visible inadequate amount of funds would simply fuel the run. However, the commitment of unlimited funds ultimately entails unlimited risks, including the possibility of strategic defaults and hold-up problems that may arise as the CIF's share of total claims on the country starts to mount.

An additional reason to limit the size of the CIF is that, if the liquidity crisis is not undone during the life of the loan, or if it derives into a solvency crisis, CIF assistance is likely to be phased into a Fund program. Therefore, the size of the CIF loan should not exceed the amount of resources commonly available under those programs. Indeed, the need to preserve the leverage necessary to impose conditionality on key policy measures may call for a CIF size below that amount.

The insurance coverage condition coupled with the need to limit CIF exposure (that is, the size of CIF lending over GDP) entails a limit on the share of short-term debt over GDP. For example, if the CIF is limited to 8.5 percent of GDP, and the minimum insurance coverage is set at 85 percent, this would imply a sub-ceiling on short-term debt of 10 percent of GDP.

In Table 5, we assume 85 percent insurance coverage and compute the proportion of the IMF quota that this would represent for our EM sample. The average is 4.7 times the quota, which makes the facility large but not excessively so. Indeed, IMF disbursements were about 5 times the quota in Mexico (1995), 18 times in Korea (1998), 7.7 times in Brazil (2001 and 2002 combined), and 17 times in Turkey (1999-2001 and 2002 combined). ${ }^{44}$

\section{E. Procedures}

As important as the ex ante conditions are the safeguards that should be in place once the CIF is drawn on. These involve, essentially, restrictions on the actions that both the country and the CIF can undertake.

Regarding the former, it is important that prudent fiscal policies be maintained while the country is borrowing from the facility. For the solvency of the CIF, it is crucial that the country should not be allowed to dilute CIF claims by issuing substantial amounts of net debt (that is, debt that is not applied to the service of old debt, including the CIF loan). This suggests that the CIF should impose restrictions to prevent the country from using the facility to pursue unsound fiscal policies. There are few concepts, however, that stir up more controversy than a quantitative definition of a prudent fiscal policy.

${ }^{44}$ See Roubini and Setser (2004). 
Table 5. IMF Quotas and CIF Coverage

\begin{tabular}{lcc}
\hline Country & $\begin{array}{c}\text { IMF Quota/GDP } \\
\text { (In percent) }\end{array}$ & Maximum Coverage/Quota \\
\hline & & \\
Algeria & 2.7 & 3.1 \\
Argentina & 2.3 & 3.7 \\
Brazil & 0.9 & 9.4 \\
Bulgaria & 4.5 & 1.9 \\
Chile & 1.7 & 5.0 \\
China & 0.6 & 14.2 \\
Colombia & 1.4 & 6.1 \\
Costa Rica & 1.3 & 6.5 \\
Croatia & 1.8 & 4.7 \\
Egypt & 1.9 & 4.5 \\
Hungary & 1.8 & 4.7 \\
India & 1.0 & 8.5 \\
Indonesia & 1.4 & 6.1 \\
Israel & 1.2 & 7.1 \\
Jordan & 2.4 & 3.5 \\
Korea & 0.4 & 21.3 \\
Malaysia & 2.0 & 4.3 \\
Mexico & 0.6 & 14.2 \\
Morocco & 1.9 & 4.5 \\
Nigeria & 5.1 & 1.7 \\
Pakistan & 2.1 & 4.0 \\
Peru & 1.5 & 5.7 \\
Philippines & 1.6 & 5.3 \\
Poland & 0.9 & 9.4 \\
Russia & 1.9 & 4.5 \\
South Africa & 1.6 & 5.3 \\
Thailand & 1.1 & 7.7 \\
Turkey & 0.6 & 14.2 \\
Ukraine & 3.9 & 2.2 \\
Uruguay & 3.8 & 2.2 \\
& & $\mathbf{4 . 7}$ \\
Average & $\mathbf{1 . 8}$ & \\
& & \\
\hline
\end{tabular}

Source: IMF staff estimates, International Financial Statistics, and World Economic Outlook database; and J.P. Morgan. 
Operationally, one could at least be guided by internal consistency. If prudent fiscal policies are defined (for the eligibility criteria) as a deficit below 3 percent of GDP in the 3 previous years, there is no reason to believe that a similar criterion (that is, a deficit below 3 percent in the current year) would not apply once the country resorts to the CIF. Accordingly, it would be reasonable to require that a country commit not to exceed a deficit of 3 percent while borrowing from the facility.

A related question concerns the need to prevent countries from using the facility for purposes different from its intended objective of public debt rollover. Specifically, a country may apply CIF resources to a private sector bailout (for instance, by buying at book value nonperforming loans or other distressed assets), and such transactions might not be reflected in the fiscal deficit as usually defined. A possible solution for this problem would be to assess eligibility based on the new IMF definition of overall fiscal balance (IMF, 2001). ${ }^{45}$ More generally, irrespective of the definition agreed upon, it would be important that the IMF (e.g., through Article IV consultations) monitor countries' accounting standards and denounce creative accounting practices.

In addition, it is important that countries that access the facility maintain good relations with other creditors. Related to this, the country would be diverting CIF funds if, after assistance is granted, it defaults on its private creditors-a situation that the CIF is intended to avert in the first place. ${ }^{46}$ Thus, a default on any private creditor should be tantamount to a default on the CIF.

On the CIF side, the main concern with the provision of liquidity is the time inconsistency problem arising if, once the (renewed) loan matures, the country still faces a steep risk premium in private capital markets. As noted, this situation is unlikely if the run was caused by nonfundamental factors. However, because of their deliberate simplicity, the eligibility conditions described above may not always filter out cases in which financial distress is the symptom of more fundamental problems. Those countries will still have the option of requesting a Fund program. Indeed, even in such cases the CIF may play a positive role as a buffer that gives distressed countries the time to negotiate an IMF program without the urgency of a financial collapse. Thus, the complementarity of the CIF and existing Fund facilities can credibly avoid the temptation to renew CIF loans repeatedly to avoid real hazard - a problem that, unfortunately, will be present in any Fund program that replaces the CIF.

${ }^{45}$ According to IMF (2001), in the overall fiscal balance "net lending/borrowing [is] adjusted through the rearrangements of transactions in assets and liabilities that are deemed to be for public policy purposes. Notably all proceeds under privatization [...] would be included as financial item; and subsidies given in the form of loans would be recognized as an expense" (p.53).

${ }^{46}$ Needless to say, the country should be current on all its debt at the request date. 
One additional concern may arise in cases in which new developments in an eligible country threaten to undermine fundamentals in the future. While there may be no realistic way to incorporate this input in the computation of the criteria, the CIF may want to include, as a last safeguard, an escape clause that allows eligibility to be suspended in light of extraordinary events. These could range from situations in which the CIF detects solvency issues not captured by the eligibility criteria (for example, hidden liabilities) to episodes of civil unrest or natural disasters that could compromise the country's finances. In this regard, to reduce the margin for political interference - and preserve the predictability of the facility - suspensions may require a supermajority vote of member countries.

\section{F. The Exit Problem}

Although the current facility removes most of the factors identified in IMF (2003) behind the lack of demand for the CCL, there is one aspect that remains unaddressed: the exit problem. More precisely, to the extent that a CIF eligible country is blessed by lower and more stable financing costs, the facility may amplify the impact of a shock that moves a borderline country closer to the eligibility threshold in any of the relevant dimensions.

Imagine, for simplicity, that the CIF is based on a single eligibility criterion: a debt-to-GDP ratio below 60 percent. A relatively minor economic contraction or a slight real exchange rate adjustment may throw an eligible country with a debt-to-GDP ratio in the vicinity of 60 percent on the wrong side of the threshold, inducing an immediate upward adjustment in market interest rates that may, by itself, precipitate a run on the now uninsured economy. ${ }^{47}$ In this extreme example, it is conceivable that borderline countries may condemn the facility as a new source of volatility.

While there is no simple way to undo this problem, it can be mitigated by "smoothing" the eligibility criteria to reduce their sensitivity to shocks. On the one hand, one could correct the weight of foreign currency debt according to the perceived overvaluation of the local currency (although a consensus about the equilibrium real exchange rate is always hard to find). On the other hand, ratios may be computed based on medium-term (cyclically adjusted) averages (although this avenue would detract from the predictability of the whole scheme). We believe that the use of moving averages as proposed above represents a sensible compromise on this front, although the issue certainly deserves a deeper analysis.

\footnotetext{
${ }^{47}$ Countries that are already borrowing from the CIF but fear that they will not be eligible for renewal may preempt market reaction by entering into a precautionary IMF program.
} 


\section{FinAL REMARKS}

The view that many of the financial crises of the past decade have had a self-fulfilling component is gaining increasing support. Against this background, a few observers have highlighted the shortcomings of current IFI lending policies and the need for easier and more rapid access to international liquidity support. However, more often critics have blamed IFI packages for undermining market discipline and policymakers' incentives through their excessive largesse. As a result, the debate on how to reform the international financial architecture has centered on how to limit financial assistance rather than on how to make it more accessible.

The untested presumption that financial assistance reduces the stimulus to put in place sustainable policies is not necessarily true, particularly when crises are triggered by factors beyond the policymaker's control (Cordella and Levy Yeyati, 2004). Given that the political payoffs of long-run policies are severely reduced if these policies are derailed (or if the policymaker is voted out of office) as a result of a financial collapse, the probability of facing a self-fulfilling liquidity crisis is likely to tilt the policymaker's preference toward short-run objectives. On the contrary, if the country is provided with some degree of insurance against liquidity runs, long-run efforts would be ultimately rewarded, inducing the right incentives.

This argument applies fully to the CIF outlined in this article. If we accept that the liquidity crises the facility is designed to deal with are the consequence of a multiple-equilibria problem (and are thus inherently exogenous to the policymaker's decisions), moral hazard concerns should be necessarily minor, and the positive incentive effects of the insurance scheme would likely dominate. To these we should add the incentives arising from the eligibility conditions: countries would be willing to embrace sustainable policies to meet the eligibility criteria and be able to access the facility. In this respect, the CIF would replace the standard ex post conditionality by voluntary conditionality.

In addition, the CIF would reduce the need for costly hoarding of excess international reserves in eligible countries. Alternatively, it would complement the existing facilities offered by IFIs, particularly in the form of IMF-led rescue packages. As the name indicates, these packages are intended to rescue countries facing a critical condition. As such, they work as safety belts: they save the passengers' lives but do not prevent the car from being totaled. The CIF, by contrast, would prevent avoidable accidents.

In sum, while a well-designed CIF that prevents liquidity runs should be very infrequently (if ever) used, its impact should be visible in an increasing number of eligible countries and a growing stability of emerging markets risk premia. This is indeed the metric in which the success of the CIF should be measured. 


\section{References}

Borensztein, E., and P. Mauro, 2004, "The Case for GDP-Indexed Bonds," Economic Policy, Vol. 19, pp. 165-216.

Broda, C., and E. Levy-Yeyati, 2003, "Dollarization and the Lender of Last Resort," in Dollarization: Debates and Policy Alternatives, ed. by E. Levy-Yeyati, and F. Sturzenegger, (Cambridge, Massachusetts: MIT Press).

Caballero, R., and S. Panageas, 2003, "Hedging Sudden Stops and Precautionary Recessions: A Quantitative Framework,” NBER Working Paper No. 9778 (Cambridge, Massachusetts: National Bureau of Economic Research).

— , 2004, "Contingent Reserves Management: An Applied Framework," NBER Working Paper No. 10786 (Cambridge, Massachusetts: National Bureau of Economic Research).

Calvo, G., 1988, "Servicing the Public Debt: the Role of Expectations," American Economic Review, Vol. 78, pp. 647-61.

Cohen, D. and Portes, R., 2004, "Towards a Lender of First Resort," CEPR Discussion Paper No. 4615 (London: Centre for Economic Policy Research).

Cole, H, and T. Kehoe, 1996, “A Self-fulfilling model of Mexico's 1994-95 Debt Crisis,” Journal of International Economics, Vol. 41, pp. 309-30.

Cordella, T., and E. Levy Yeyati, 2003, "Bank Bailouts: Moral Hazard vs. Value Effect," Journal of Financial Intermediation, Vol. 12, pp. 300-30.

—_, 2004, “Country Insurance,” IMF Working Paper No. 04/148 (Washington: International Monetary Fund).

Council on Foreign Relations Task Force, 1999, Safeguarding Prosperity in a Global Financial System: The Future International Financial Architecture (Washington: Institute for International Economics.

De Vries, M., 1985, The International Monetary Fund, 1972-1978: Cooperation on Trial (Washington: International Monetary Fund).

Diamond, D., and P. Dybvig, 1983. "Bank Runs, Deposit Insurance, and Liquidity,” Journal of Political Economy, Vol 3 No. 91, pp. 401-19.

Fischer, S., 1999, “On the Need for an International Lender of Last Resort,” paper delivered at the joint luncheon of the American Economic Association and the American Finance Association, New York, January 3, 1999.

Freixas, X., 1999, “Optimal Bail-Out, Conditionality and Constructive Ambiguity,” LSE Financial Market Group Discussion Paper No. 237 (London: London School of Economics). 
Goodhart, C., 1995, The Central Bank and the Financial System (Cambridge, Massachusetts: MIT Press).

Goodhart, C., and H. Huang, 1999, “A Model of Lender of Last Resort," IMF Working Paper No. 99/39 (Washington: International Monetary Fund).

Goldstein, Morris, 2001, “IMF Structural Conditionality: How Much Is Too Much?” Institute for International Economics Working Paper No. 01-04 (Washington: Institute for International Economics).

Hausmann R., and A. Velasco, 2004, “The Causes of Financial Crises: Moral Failure Versus Market Failure," available on line at: http://ksghome.harvard.edu/ avelasco/Files/Research/Causes_of_Crises_Dec2004.pdf

Huang, H., 2004, “Asian Regional Financial Initiatives,” unpublished manuscript (Washington: International Monetary Fund)

International Financial Institution Advisory Commission, 2000, Report of the International Financial Institution Advisory Commission, Allan H. Meltzer, Chairman (Washington).

IMF, 1994, Short-Term Financing Facility (EBS/94/193)

IMF, 2001, Government Finance Statistics Manual 2001, available online at: http://www.imf.org/external/pubs/ft/gfs/manual/

IMF, 2003, Review of Contingent Credit Lines (IMF SM/03/64), available online at: http://www.imf.org/external/np/pdr/fac/2003/021103.htm

Jeanne, O., and J. Zettelmeyer, 2001, "International Bailouts," Economic Policy, Vol. 33, pp. 408-32.

Kaplan, E., and D. Rodrik, 2001, “Did the Malaysia Capital Control Work?” NBER Working Paper No. 8142 (Cambridge, Massachusetts: National Bureau of Economic Research).

Ranciere, R., Tornell, A., and F. Westerman, 2003, "Crises and Growth: A Re-evaluation," NBER Working Paper 10073 (Cambridge, Massachusetts: National Bureau of Economic Research).

Roubini, N., and B. Setser, 2004, “Bailout or Bail-Ins,” (Washington: Institute for International Economics).

Sturzenegger, F., and J. Zettelmeyer, 2004, "Haircuts," available online at: http://www.utdt.edu/ fsturzen/haircuts4.pdf

Zettelmeyer, J., 2000, "Can Official Crisis Lending be Counter-productive in the Short-Run?" Economic Notes, Vol. 29, pp. 13-29. 